\title{
Production potential of the Kabardino-Balkarian Republic pasture ecosystems
}

\author{
Aida Tamahina ${ }^{1, *}$, and Urfa Turan Ogly Turabov $^{2}$ \\ ${ }^{1}$ Kabardino-Balkarian State Agricultural University named after V.M.Kokov, Lenin Avenue, 1V, \\ 360030 Nalchik, Russia \\ ${ }^{2}$ Azerbaijan State Agricultural University, AZ2000, Ataturk Avenue, 450, Ganja, Azerbaijan
}

\begin{abstract}
The pasture digression of meadows followed by soil deflation is one of the pressing environmental problems. This problem is typical for mountain pastures that are constantly in economic circulation. The article presents the results of a geobotanical survey of the Zolsky pastures on the territory of the Kabardino-Balkarian Republic in 2018-2020. The results of a geobotanical survey show that the pasture phytocenoses are characterized by high floristic diversity due to the heterogeneity of edaphic and orographic factors. The flora of the pastures is represented by postwood moist sedgy-and-tussock-grass, mesophilic woodreed-and-agrostidinic grass, cereal forb, forbs cereal mesophilic and subalpine meadows, low sedgy meadow steppes. The average yield for the pasture period varies from 7.2 to 16.6 centners/ha of dry eaten mass. The consequence of prolonged pasturage and excessive pasture load was a decrease in alpha and beta diversity, the formation of low-productive secondary plant communities of non-food, poisonous and weed grasses, the destruction of sod and soil outcropping. Restoration of degraded pasture ecosystems is possible on the basis of ecological intensification, which provides for the regulation of pasture loads, adherence to grazing terms, phytomelioration using perennial grasses, and short-term isolation of pastures from grazing. This will prevent erosion processes, increase biodiversity, productivity, forage value of grass stand and stability of pasture ecosystems.
\end{abstract}

\section{Introduction}

Pasture ecosystems perform the production (production of feed for livestock), environmentforming (air and water purification, soil protection from erosion, formation of soil bioproductivity, regulation of biological processes and regulation of the number of living organisms), information (genetic resources, information on the structure and functioning of natural ecosystems) and recreational services. Due to the fact that the main ecosystem service of pastures is a production service, the assessment of the volume of ecosystem services of pasture ecosystems in Russia is carried out by the share of natural fodder eaten by livestock, the average amount of fodder eaten by livestock, the number of fodder units that natural pastures produce per year per 1 hectare. area of the region (on average, 29 centners of feed units per year). In general, the used volume of the productive ecosystem

* Corresponding author: aida17032007@yandex.ru 
services of the majority of pasture ecosystems in Russia is many times less than their actual volume. The share of natural fodder eaten by livestock in most of the territory of Russia does not exceed $4 \%$. However, in the mountainous regions of Russia, the degree of pasture use is close to $50 \%$, and the share of natural fodder eaten by livestock reaches $19 \%$ [1].

Despite the enormous ecosystem and economic importance, the current state of pasture ecosystems is of serious concern due to their intensive and irrational exploitation. One of the urgent environmental problems is the degradation of pasture ecosystems, which manifests itself in a decrease in the productivity and quality of herbage, changes in the composition of flora under the influence of pasture, technical, recreational digression and pesticide pollution [2, 3]. An increase in the intensity of grazing in pasture meadows leads to a simplification of the structure and a decrease in species diversity, an increase in the role of digression-resistant species of forbs and soil, a decrease in the balance of $\mathrm{N}$ and $\mathrm{P}$ in the soil, its compaction and desiccation $[4,5,6]$.

This problem is clearly manifested on the territory of the Kabardino-Balkarian Republic (KBR), where the meadows in economic circulation are constantly used as hayfields and pastures. The area of pastures and hayfields in the KBR is 311 and 58.7 th ha, respectively. The distant pastures, where annually up to $75 \%$ of the total livestock of the republic are kept, are of particular value. Ineffective and disorderly use of natural forage lands in the republic has led to a sharp decline in returns and an increase in environmental stress. This is especially true of mountain hayfields and pastures, the main part of which is degraded, subject to erosion, littered with harmful, poisonous and inedible grasses [7, 8].

In connection with the above, the purpose of the study was to assess the current state of the KBR pasture ecosystems.

\section{Materials and Methods}

The main research method was the geobotanical survey of the Zolsky pastures (Zolsky district of the KBR) on an area of 950 hectares in 2018-2020. The description of phytocenoses was performed accounting areas (AA) of $100 \mathrm{~m}^{2}$. The association was named pursuant to the dominant species. The projective cover of the species was assessed as a percentage of the AA total area. The grass stand was disassembled into economic groups (cereals, sedges, legumes, forbs, poisonous grasses) with the selection of well and satisfactory eaten ones. When describing edaphic conditions, the type and method of soil moistening were noted. The economic characteristics of the pastures were given according to the participation of useful and harmful plants in the herbage, the state of the herbage in relation to its trampedness and economic productivity. The level of pasture digression was assessed on a scale: 1 - weak, 2 - moderate, 3 - medium, 4 - strong. To monitor alpha and beta diversity, forms of geobotanical descriptions for individual communities were used. Alpha diversity was assessed based on the total number of species in the community based on the data of route counts and descriptions of sample plots, the beta diversity was assessed using Whittaker measure $\left(\beta_{w}\right)$. Statistical processing included determination of the correlation dependence (r) between the studied parameters of pasture phytocenoses and cluster analysis.

\section{Results and Discussion}

Zolsky pastures are located in the mountainous zone of the KBR (Malye Kuraty tract) at the junction of the forest and subalpine belts. The vegetation formed on mountain-meadow chernozem-like, mountain meadow-boggy soils, on plateaus and gentle slopes, on steep slopes of the eastern, southeastern and western exposures in a cool climate, is very diverse. 
The flora of the pastures is represented by post-forest moist sedge-pike, mesophilic reedfield grass, cereal-forb, forb-cereal mesophilic, subalpine meadows and low sedge meadow steppes. In the surveyed area, 11 types of phytocenoses were identified (Table 1).

Table 1. The main types of pasture phytocenoses in the Zolsky district.

\begin{tabular}{|c|c|c|c|c|}
\hline $\begin{array}{c}\mathrm{It} \\
\mathrm{e} \\
\mathrm{m} \\
\mathrm{N} \\
\mathrm{o}\end{array}$ & Phytocenosis type & Soil type & $\begin{array}{l}\text { Productivity for } \\
\text { the pasture } \\
\text { period, } \mathrm{kg} / \mathrm{ha} \text { of } \\
\text { dry eaten mass }\end{array}$ & Hydration \\
\hline \multicolumn{5}{|c|}{ Mountain belt } \\
\hline 1 & Sedge-pike, pike-sedge & $\begin{array}{l}\text { Mountain meadow- } \\
\text { boggy }\end{array}$ & 16.6 & $\begin{array}{l}\text { atmospheric, } \\
\text { soil and singer }\end{array}$ \\
\hline 2 & $\begin{array}{l}\text { Postwood mesophilic } \\
\text { cereals, cereal-sedge- } \\
\text { forb }\end{array}$ & $\begin{array}{l}\text { Mountain meadow } \\
\text { chernozem }\end{array}$ & 16.8 & atmospheric \\
\hline 3 & Forbs-field-grass & $\begin{array}{l}\text { Mountain } \begin{array}{r}\text { meadow } \\
\text { chernozem-like gleyic } \\
\text { heavy loamy }\end{array} \\
\end{array}$ & 12.1 & atmospheric \\
\hline 4 & $\begin{array}{l}\text { Heavily trampened } \\
\text { cereal-weedy-forb }\end{array}$ & $\begin{array}{l}\text { Mountain meadow } \\
\text { chernozem-like leached } \\
\text { gleyic heavy loamy }\end{array}$ & 10.0 & atmospheric \\
\hline 5 & Forbs and cereals & $\begin{array}{l}\text { Mountain meadow } \\
\text { chernozem-like friable } \\
\text { stern loamy }\end{array}$ & 11.0 & atmospheric \\
\hline 6 & Cereal-herb-low-sedgy & $\begin{array}{l}\text { Mountain-meadow } \\
\text { chernozem-like friable } \\
\text { soddy heavy loamy } \\
\text { surface-gravel-stony }\end{array}$ & 13.2 & atmospheric \\
\hline 7 & $\begin{array}{l}\text { Forbs-field-grass, reed- } \\
\text { field grass-field }\end{array}$ & $\begin{array}{l}\text { Mountain meadow } \\
\text { chernozem-like friable } \\
\text { stern loamy }\end{array}$ & 7.2 & atmospheric \\
\hline 8 & $\begin{array}{l}\text { Grass-forb with low } \\
\text { sedge }\end{array}$ & $\begin{array}{l}\text { Mountain meadow } \\
\text { chernozem-like friable } \\
\text { stern loamy }\end{array}$ & 6.6 & atmospheric \\
\hline 9 & Forb-low-sedge & $\begin{array}{ll}\begin{array}{l}\text { Mountain } \\
\text { chernozem }\end{array} & \text { meadow } \\
\end{array}$ & 7.3 & atmospheric \\
\hline \multicolumn{5}{|c|}{ Alpine belt } \\
\hline $\begin{array}{l}1 \\
0\end{array}$ & Forbs and cereals & $\begin{array}{l}\text { Mountain meadow } \\
\text { chernozem-like gleyic } \\
\text { heavy loamy }\end{array}$ & 10.6 & atmospheric \\
\hline $\begin{array}{l}1 \\
1\end{array}$ & $\begin{array}{l}\text { Forb-cereal meadow } \\
\text { red-tailed fescue grass }\end{array}$ & $\begin{array}{l}\text { Mountain meadow } \\
\text { chernozem-like friable } \\
\text { soddy heavy loamy }\end{array}$ & 15.4 & atmospheric \\
\hline
\end{tabular}

To assess alpha diversity, 11 most characteristic geobotanical descriptions were selected, in which 85 species were registered.

Sedge-pike and pike-sedge type of pastures is found on gentle slopes of northern exposure, plateaus, in depressions between slopes. Humidification is atmospheric, ground and drip. The grass cover of these meadows is quite dense. UP-1 is dominated by Deschampsia cespitosa, Carex pallescens, C. leporina, C. melanostachya and Luzula multiflora. Minor types are Festuca pratensis, Veratrum lobelianum, Astrantia maxima, Gladiolus communis, Filipendula vulgaris, Geranium sanguineum. Carex acuta, Juncus gerardii are abundant in bushy areas, and related species are Filipendula ulmaria, Anthriscus nemorosa and Trollius ranunculinus Scarce are Poa longifolia, Calamagrostis phragmitoides. The projective cover is $65-90 \%$, the height of the grass stand varies from 40 to $60 \mathrm{~cm}$. 
Postwood mesophilic meadows are represented by forbs-field grass and reed-field grass types of pastures on gentle and steep slopes of western and northern exposures. The dominants of phytocenoses on AA-2 are Agrostis planifolia and Calamagrostis phragmitoides, and the codominants are Anthriscus nemorosa, Bromopsis variegata and Phleum phleoides. Rhinanthus serotinus, Gladiolus communis, Geranium sanguineum, Filipendula ulmaria, Valeriana officinalis, Dactylorhiza urvilleana, Veratrum lobelianum, Brachypodium pinnatum, Cirsium obvallatum, Galium ruthenicum take a significant part in the composition of the herbage. Legumes are represented by Trifolium hybridum, $T$. pratense, T. ambiguum, Vicia angustifolia, Lotus caucasicus, Medicago falcata. The projective cover is $90-100 \%$, the height of the herbage is $40-60 \mathrm{~cm}$. Infestation with poisonous and harmful herbs (Veratrum lobelianum, Ranunculus montanus, Cirsium obvallatum) reaches $5 \%$.

Grain-weedy-forb modification of pastures is noted on the plateau and gentle slopes of the northern exposure. The site is heavily trampened. Deschampsia cespitosa, Poa pratensis, Alchemilla xanthochlora, Ranunculus polyanthemos and $R$. montanus grow on AA-3. Poisonous, harmful and weeds are abundant - Veratrum lobelianum, Cirsium obvallatum, Rumex confertus, Ranunculus montanus, Urtica dioica. The total projective cover is $55-60 \%$. Height of grass canopy is $50-60 \mathrm{~cm}$.

Postwood steppe forbs-cereal pastures are represented by forbs-meadow red-tailed fescue grass and herb-gramineous types. The herb-meadow red-tailed fescue grass pasture type is found on the gentle slope of the northeastern exposure. The basis of the AA-4 herbage is Festuca pratensis, Agrostis planifolia, Alchemilla xanthochlora, Leontodon hispidus, Carum carvi, Cirsium obvallatum. Veratrum lobelianum is abundant in the lower part of the slope. The projective cover is $85-90 \%$. Height of grass canopy is $10-30 \mathrm{~cm}$.

The herb-cereal type of pastures is noted on the gentle slopes of the northern, northwestern exposure and the steep slopes of the eastern exposure. The dominants on AA5 are Agrostis planifolia, Bromopsis variegata, Phleum phleoides, Briza media, Festuca ovina. Minor types are Brachypodium pinnatum, Poa pratensis, Koeleria caucasica, Carex pallescens. The most abundant legumes are Trifolium hirtum and Lotus caucasicus. Wild grasses are Filipendula vulgaris, Astrantia trifida, Achillea millefolium, Veratrum lobelianum. The projective cover is $100 \%$, the height of the herbage is $35-40 \mathrm{~cm}$.

In the herbage of the steep-slope forb-cereal pasture (AA-6) dominate Bromopsis erecta, Koeleria luerssenii, Helictotrichon pubescens, Carex humilis. Among legumes, Anthyllis macrocephala, Trifolium ambiguum, T. montanum, Vicia angustifolia, V. varia are present in significant quantities in the herbage. Forbs are represented by steppe (Galium verum, Thymus serpyllum, T. marschallianus) and meadow-steppe specie (Filipendula vulgaris, Origanum vulgare, Psephellus leucophyllus, Salvia verticillata, Plantago atrata). The projective cover is $90-95 \%$, the height of the herbage is $15-40 \mathrm{~cm}$.

The cereal-forb type of pastures is found on the steep slopes of the western exposure. On AA-7, Bromopsis erecta, Brachypodium pinnatum, Helictotrichon pubescens, Briza media, Festuca ovina dominate among cereals, the codominant is Carex humilis. The most abundant forbs are Astrantia trifida, Pyrethrum coccineum, Filipendula vulgaris, Leontodon hispidus, Origanum vulgare. There were small amounts of Scabiosa bipinnata, Potentilla erecta, Anthemis melanoloma, Geranium sanguineum, Ranunculus caucasicus. Legumes are represented by Trifolium ambiguum, T. montanum, T. hirtum, Onobrychis biebersteinii, Vicia angustifolia, Lotus caucasicus. The projective cover is $85 \%$, including legumes $-10 \%$, the height of the herbage is $15-40 \mathrm{~cm}$.

Grass-forb-low-sedge and forb-low sedge types of pastures are found on steep and gentle slopes of the southern, southeastern exposure. The dryness of the habitat is due to the runoff of atmospheric precipitation from the slopes. The dominants in the herbage of gentle 
slopes (AA-8) are Carex humilis, Festuca pratensis, Bromopsis erecta, Origanum vulgare, Alchemilla xanthochlora and Trifolium ambiguum. On steep slopes, grasses (Bromopsis erecta, Koeleria luerssenii, Festuca ovina) and herbs (Psephellus leucophyllus, Plantago atrata, Thymus nummularius) dominate in the herbage. Legumes include Anthyllis macrocephala and Lotus caucasicus. The projective cover is $70-80 \%$, the height of the herbage is $15-30 \mathrm{~cm}$. Contamination (more than 3\%) with the poisonous Euphorbia iberica was noted.

The vegetation of the subalpine belt is represented by mesophilic and steppe grass-grass pastures on gentle slopes of northern and northeastern exposure. The dominants of the mesophilic herb-grass pasture (AA-9) are Bromopsis erecta, Calamagrostis phragmitoides, Agrostis planifolia, Astrantia trifida, Betonica macrantha, Inula orientalis, Alchemilla xanthochlora amd Veratrum lobelianum. Associated species are Myosotis alpestris, Anemonastrum fasciculatum, Trollius ranunculinus, Carex tristis, C. pallescens. Legumes, in particular Trifolium ambiguum and T. hirtum, play a significant role in the composition of the herbage. The projective cover is $90 \%$, the height of the herbage is $45-50 \mathrm{~cm}$.

Bromopsis erecta, B. variegata, Koeleria caucasica, Agrostis planifolia dominate in the herbage of the steppe forb-cereal type (AA-10). The minor species are Festuca ovina, Carex humilis and C. tristis. Festuca woronowii occurs only once. Legumes are represented by Trifolium montanum, T. ambiguum, T. hirtum and Vicia angustifolia. The most abundant forbs are Betonica macrantha, Lomelosia caucasica, Inula orientalis, Leontodon hispidus, Astrantia trifida. Veratrum lobelianum was noted in the hollows (about 4\% of the projective cover). Sedum acre, Thymus marschallianus, Festuca valesiaca are found at rock outcrops. The projective cover reaches $100 \%$, the height of the herbage is $50 \mathrm{~cm}$.

On average, the annual stocks of pasture fodder amount to 11.53 thousand c/ha of dry eaten mass. Most of the surveyed Zolsky pastures (about 70\%) are characterized by poor and medium quality forage. At the same time, in terms of species composition and relief (slopes with a steepness less than $25^{\circ}$ ), all pastures are suitable for grazing cattle.

On the territory of the Zolsky pastures, small areas of little grazed vegetation (reference areas) have been preserved on the slopes of the western, northeastern and southeastern exposure. Straight-edged, mixed-herb-low-sedge and herb-variegated associations grow here. The alpha diversity of the reference site (AA-11) is formed by 32 species. The projective cover is $100 \%$, the height of the herbage is $60-65 \mathrm{~cm}$. The results of monitoring of pasture phytocenoses of the Zolsky pastures are presented in Table 2.

Table 2. Parameters of the surveyed pasture phytocenoses.

\begin{tabular}{|l|c|c|c|c|c|}
\hline UP & $\begin{array}{c}\text { Level of } \\
\text { pasture } \\
\text { digression, } \\
\text { points }\end{array}$ & $\begin{array}{c}\text { Species } \\
\text { richness }\end{array}$ & $\begin{array}{c}\text { Average } \\
\text { projective } \\
\text { cover, } \%\end{array}$ & $\begin{array}{c}\text { Average } \\
\text { height of } \\
\text { herbage, cm }\end{array}$ & $\begin{array}{c}\text { Productivity of } \\
\text { aboveground } \\
\text { phytomass, } \\
\mathrm{kg} / \mathrm{m}^{2}\end{array}$ \\
\hline 1 & 4 & 18 & 78 & 40 & 0.14 \\
\hline 2 & 2 & 22 & 97 & 50 & 0.17 \\
\hline 3 & 4 & 10 & 58 & 55 & 0.10 \\
\hline 4 & 3 & 8 & 87 & 20 & 0.07 \\
\hline 5 & 4 & 15 & 98 & 38 & 0.12 \\
\hline 6 & 2 & 17 & 93 & 28 & 0.14 \\
\hline 7 & 2 & 22 & 85 & 30 & 0.13 \\
\hline 8 & 4 & 14 & 75 & 20 & 0.13 \\
\hline 9 & 2 & 24 & 90 & 48 & 0.11 \\
\hline 10 & 2 & 21 & 100 & 50 & 0.15 \\
\hline 11 & 1 & 32 & 100 & 63 & 0.22 \\
\hline
\end{tabular}


The following gradations of correlation were revealed between the studied parameters: moderate $(r=0.3-0.5)$ between the level of pasture digression and the average height of the herbage, the average projective cover and the productivity of the aboveground phytomass; average $(r=0.51-0.70)$ between the level of pasture digression, species richness and productivity of aboveground phytomass, as well as between species richness, average projective cover and average height of herbage; high $(\mathrm{r}=0.71-0.90)$ between species richness and productivity of aboveground phytomass, average projective cover and level of pasture digression. The cluster analysis shows that the main factor of the productivity and biodiversity of pasture ecosystems is the level of pasture digression (Fig. 1).

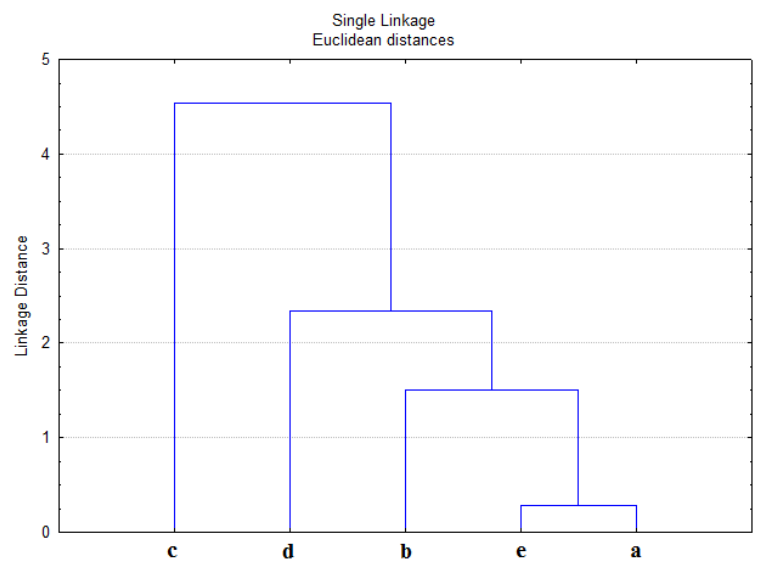

Fig. 1. Dendrogram of clustering parameters of pasture phytocenoses: a - level of pasture digression; $\mathrm{b}$ - species richness; $\mathrm{c}$ - average projective cover; $\mathrm{d}$ is the average height of the grass stand; e - productivity of aboveground phytomass.

The beta-diversity of the Zolsky pastures is generally characterized by a $\beta_{w}$ value of 3.63. In communities with a moderate level of pasture digression, $\beta_{w}$ decreases to 2.72 , and with a moderate and strong level - to 2.40 . The beta diversity of the reference plot and phytocenoses with moderate pasture digression is higher $(\beta w=3.26)$ compared to the same indicator for the reference plot and phytocenoses with strong pasture digression $(\beta w=$ 2.74). This indicates an increase in the number of common species, a decrease in biodiversity and resistance of plant communities with an increase in pasture load, regardless of the type of phytocenosis, spatial and soil heterogeneity.

Due to the duration of grazing and excessive pasture load in the ecotopes of the Zolsky pastures, negative trends are observed:

1) an increase in forbs in the composition of forb-reed and forb-variegated rangelands, the formation of low-productive secondary clumps of Alchemilla xanthochlora, destruction of sod and outcropping of the soil, the development of non-eating ruderal plants on the released substrate; on the plateaus and gentle slopes of the northern exposure, replacing grass stands with good fodder plants with weeds and poisonous vegetation;

2 ) the formation of a network of paths and gullies in places of excessive grazing, soil swelling with erosion of sod on steep slopes and the formation of landslide and erosional landscapes.

In this regard, we should note that in the KBR, soils on an area of more than 290 th ha ( $23 \%$ of the total area of the republic), including 99 th ha of pastures, are subject to intense water erosion. The water erosion of land leads to a sharp loss of humus (annually up to 6.1 $\mathrm{t} / \mathrm{ha}$ ). Over a ten-year period, the humus content in the topsoil of the Zolsky district decreased from 7.2 to $6.4 \%$ [9]. 
A high pasture load on natural pastures is a powerful destructive ecological factor affecting the populations of valuable forage legumes and grasses, which requires the search for new approaches, methods and means to increase the efficiency and sustainability of natural forage lands. In areas subject to significant anthropogenic pressure, an important condition for the conservation of flora biodiversity is the implementation of various tactics and life strategies by plants [10]. The population dynamics of meadow plants is determined not only by grazing, fertilization and mowing, but also by the heterogeneity of the landscape and the fragmentation of the habitat. A regional species pool in a heterogeneous landscape is characterized by a higher species richness, as a result of which it can be the main source of the species richness of pasture phytocenoses, depending on the ability of species to spread, their abundance, seed bank and their germination.

To assess the species composition of meadow plants, an integral approach is required, based on identifying the relationship between the ability of plants to disperse and the productivity of aboveground phytomass, landscape heterogeneity, and disturbances caused by agricultural practices. Taking these factors into account will improve the efficiency of agroecological schemes for the restoration or conservation of biodiversity of pasture ecosystems [11]. The key task of the rational use of pasture ecosystems is the search for ecologically and economically efficient management regimes to maintain the ecological functionality and biodiversity of plant communities [12]. Therefore, to predict the botanical, functional composition and ecosystem services of pasture meadows, it is necessary to take into account the interaction between managerial, edaphic and climatic factors [13].

An important measure for the restoration of degraded pasture ecosystems is the regulation of pasture loads and compliance with the timing of grazing [14]. Grazing of pastures in the summer-autumn period compared to the spring-summer period should be less intense and short-lived. This is due to the formation of a powerful root system by plants in the fall and the enrichment of the soil with nitrogen during the decomposition of overgrown grass (autumn regrowth of grass is equivalent to the introduction of 60-120 $\mathrm{kg} / \mathrm{ha}$ of nitrogen into the soil). The grazing regime in the middle of summer is advisable on pastures with good grass regrowth in spring [15].

Important methods of pasture restoration and prevention of erosion processes are phytomelioration using perennial grasses, in particular, the Trifolium and Arrhenatherum species, which ensure the reconstruction of destroyed sod, high density and an optimal set of valuable plants in the herbage [16, 17], as well as short-term isolation of pastures from grazing, allowing to increase the productivity of herbage, species diversity of legumes and cereal components and reduce erosion processes [18, 19]. The nature reserve status excludes the practice of a purely consumerist attitude towards natural forage lands. Therefore, the use of the reserved regime of individual areas of pastures should be determined by the productive capacities of vegetation, soil cover and the state of the landscape as a whole. The listed activities underlie the ecological intensification of pasture meadow cultivation, which presupposes landscape approaches based on the rational use of the natural functional capabilities of pasture ecosystems and the potential for their sustainability [20].

\section{Conclusion}

The results of a geobotanical survey of pasture ecosystems using the example of the Zolsky pastures of the Kabardino-Balkarian Republic indicate their significant floristic diversity due to the heterogeneity of edaphic and orographic factors. The flora of the pastures is represented by postwood moist sedgy-and-tussock-grass, mesophilic woodreed-and- 
agrostidinic grass, cereal forb, forbs cereal mesophilic and subalpine meadows, low sedgy meadow steppes. Their average yield for the pasture period varies from 7.2 to 16.6 centners/ha of dry eaten mass. A negative tendency due to excessive pasture load is the formation of low-productive secondary plant communities of non-food, poisonous and weed grasses, destruction of sod and soil outcropping, and a decrease in floristic biodiversity. To restore degraded pasture ecosystems, ecological intensification is promising, providing for the regulation of pasture loads, adherence to grazing terms, phytomelioration using perennial grasses, and short-term isolation of pastures from grazing. This will prevent erosion processes, increase biodiversity, productivity, forage value of grass stand and stability of pasture ecosystems.

\section{References}

1. E. N. Bukvaryova, D. G. Zamolodchikov, Ecosystem services of Russia: Prototype of the national report. Services of land ecosystems (2016)

2. O. G. Bembeeva, Bulletin of Institute for Integrated Research of Arid Territories, 2(37) (2018)

3. N. V. Tyutyuma, G. K. Bulakhtina, Izvestia of the Lower Volga Agro-University Complex: Science and higher education, 3(39) (2015)

4. P. M. S. Muratchayeva, Works of Institute of geology of the Dagestan Scientific Center of RAS, 65 (2015)

5. A. D. Sambuu, A. B. Dapylday, N. G. Khomushku, Bulletin of science and practice, 4(9) (2018)

6. A. A. Titlyanova, Soil Science, 12 (2007)

7. A. Ya. Tamakhina, A. A. Gadieva, A. Ch. Kagermazova, Bulletin of KrasSAU, 8 (2013)

8. N. L. Tsepkova, M. N. Fisun, Mountain pastures of Kabardino-Balkaria (2005)

9. A. Ya. Glushko, D.S. Frolko, Terra economicus, 10 (3) (2012)

10. L. Bondarieva, et al., Ukrainian J. of Ecology, 9(2) (2019)

11. E. Gaujour, et al., Agron. Sustain. Dev., 32 (2012)

12. J. Liira, M. Issak, U. Jogar, M. Mandaja and M. Zobel, Annales Botanici Fennici, 46(5) (2009)

13. A. Michaud, et al., The J. of Agricultural Science, 150(2) (2012)

14. G. Gasanov, et al., Arid ecosystems, 1(54) (2013)

15. K. G. Magomedov, R. K. Kamilov, G. D. Kagirov, Scientific news, 4 (2016)

16. Yu. I. Sukharev, V. V. Borodychev, E. B. Dedova, S. A. Sangadzhiyeva, Environmenta l engineering, 5 (2011)

17. K. G. Magomedov, N. V. Berbekova, Advances in current natural sciences, 8 (2016)

18. G. K. Zvereva, Siberian ecological magazine, 16(5) (2009)

19. N. V. Elesova, Ukrainian J. of Ecology, 3 (2019)

20. P. Tittonell, Curr. Opin. Environ. Sustain, 8 (2014) 